\title{
УДК 631.147
}

\section{EFFICIENCY OF DIFFERENT MODELS OF AGROECOSYSTEMS ЕФЕКТИВНІСТЬ РІЗНИХ МОДЕЛЕЙ АГРОЕКОСИСТЕМ}

Kudria S. I. / Кудря C. I.

Candidate of Agricultural Sciences (Ph. D.), as. prof. / к. с.-г. н., dou. Kharkiv National Agrarian University named after V. V. Dokuchaiev, Kharkiv, p. v. Dokuchaevske 2, 62483 Харківський наџіональний аграрний університет ім. В. В. Докучаєва, Харків,

n. в. Докучаєвське 2, 62483

ORCID: 0000-0002-4581-8426

Tarariko Yu. O. / Тарарiко Ю. О. Doctor of Agricultural Sciences (D.), professor / d. c.-2. н., npoф. Institute of Water Problems and Reclamation NAAS, Kyiv, Vasylkivska, 37, 03022 Інститут водних проблем і меліорації НААН, м. Київ, вул. Васильківська, 37, 03022

ORCID; 0000-0001-8475-240X

Kudria N. А. / Кудря Н. А. Candidate of Agricultural Sciences (Ph. D.), as. Prof. / к. c.-г. н., доu. Kharkiv National Agrarian University named after V. V. Dokuchaiev, Kharkiv,

p. v. Dokuchaevske 2, 62483 Харківський начіональний аграрний університет ім. В. В. Докучаєва. Харків, n. в. Докучаєвське 2, 62483 ORCID: 0000-0003-3348-3515

Dehtiarova Z. O. / Дегтярьова 3. O. postgraduate student / acnipaнm

Kharkiv National Agrarian University named after V. V. Dokuchaiev, Kharkiv, p. v. Dokuchaevske 2, 62483 Харківський начіональний аграрний університет ім. В. В. Докучаєва. Харків, n. в. Докучаєвське-2, 62483 ORCID: 0000-0002-1055-4811

Анотація. Очінено потенціал біопродуктивності чорнозему типового в Лівобережному Лісостепу України в системі органічного землеробства, проаналізовано перспективні моделі аграрного виробництва $з$ отриманням органічних продуктів рослинництва та тваринництва з досягненням високого рівня прибутковості господарства. Проаналізовано п'ять перспективних варіантів розвитку підприємства, зокрема $з$ виробництва різних видів органічної продукиії: органічне зерно; переробка органічного зерна до продуктів харчування; розвиток тваринництва та біоенергетики, вирощування та переробка коренеплодів буряків иукрових; підвищення продуктивності сівозмін за рахунок високого рівня рециркуляиії біогенних елементів з органічними добривами тваринного походження.

Ключові слова: органічне землеробство, моделі, дохід, чорнозем, продуктивність, ефективність.

Вступ. Для більш повної оцінки сівозмін їх необхідно порівнювати не лише за чергуванням культур, але і за складом, виходом продукції на гектар ріллі тощо. Науково-дослідними закладами встановлено, що ефективність різних сівозмін залежить від насичення їх відповідними культурами, чергування культур у них, а також від системи обробітку грунту, рівня механізації та інших складових [1]. 
На сьогодні окремо існують два методичних підходи до аналізу ефективності виробництва сільськогосподарської продукції: енергетичний i економічний. Останній грунтується на ринкових засадах визначення ефективності виробництва в процесі відтворення сукупності виробничих ресурсів, а також враховує спожиту у виробничому процесі частку ресурсів [2].

Одними 3 головних показників економічної оцінки використання результатів науково-дослідних робіт $\epsilon$ : приріст виробництва продукції та отриманий річний економічний ефект на одиницю площі

Методика досліджень. Сівозміна, що складається iз зернових, зернобобових і круп'яних культур імітує рослинницьку галузеву структуру. Сівозміна, що включає кормові культури моделює наявність галузі тваринництва. У нашому випадку кукурудза, вико-вівсяна сумішка та соя, що дають змогу отримувати силос, сіно, сінаж і зелену масу, як обов'язкових складових раціонів годівлі тварин у молочному скотарстві. Отримані в досліді результати, зокрема рівні врожайності культур і продуктивності сівозмін, використовували при імітаційному моделюванні перспективних варіантів розвитку органічного аграрного виробництва на прикладі типового сільськогосподарського підприємства «Сільськогосподарське товариство 3 обмеженою відповідальністю «Колос 2000»» Чугуївського району Харківської області, що практично межує 3 дослідним полем на якому були проведені дослідження. Загальна площа господарства складає 2030 га.

Моделювання здійснювалося за допомогою програмного комп'ютерного комплексу «Агроекосистема» [3], який дає змогу опрацьовувати різні варіанти міжгалузевої оптимізації будь якого сільськогосподарського підприємства: впровадження системи органічного землеробства та виробництва, розвиток тваринництва, переробка продукції, виробництво біоенергії та інші складові. У даному випадку головна мета моделювання - порівняльна оцінка ефективності виробництва органічної продукції рослинництва і тваринництва та розробка підходів з формування органік-орієнтованої моделі розвитку аграрного сектора економіки України.

Результати. Проаналізуємо п’ять перспективних варіантів розвитку підприємства, зокрема з виробництва різних видів органічної продукції.

Модель № 1 передбачає перехід на виробництво органічної продукції рослинництва. Сівозміна та врожайність культур: 1 - горох - 1,9 т/га, 2 пшениця озима - 3,7 т/га, 3 - гречка - 1,2 т/га, 4 - ячмінь ярий $-2,1$ т/га. Така продуктивність забезпечується застосуванням на добриво тільки нетоварної продукції рослинництва та без використання пестицидів. Цей сценарій передбачає реалізацію зерна без переробки. За середнього розміру поля 507 га на підприємстві його середнє валове виробництво відповідно по культурах буде складати: горох або інші зернобобові культури досліджуваних сівозмін - 900 т, пшениця озима - 1800 т, гречка -600 т, ячмінь ярий -1000 т. Разом - 4300 т або 2,1 т/га.

Модель № 2 аналогічна Моделі № 1 зі створенням інфраструктури по зберіганню зерна, його поступовій переробці на крупи, фасуванню та зберіганню готової продукції. 
Модель № 3 розглядається для оцінки доцільності організації виробництва органічної продукції тваринництва. Урожайність культур: 1 - горох - 1,9 т/га, 2 - пшениця озима - 3,7 т/га, 3 - однорічні трави - 15 т/га зеленої маси, 4 кукурудза на силос - 23 т/га зеленої маси. Солома на добриво не застосовується, а використовується на потреби тваринництва. Як було встановлено у стаціонарному досліді співвідношення зерна до соломи для гороху та пшениці озимої становить $1: 1,5$.

За наявності кормової бази щільність тварин складатиме 0,76 умовних голів на гектар, річна продуктивність молочного стада - 10 тис. л молока на дійну корову або 6300 т на все дійне стадо. Крім того буде отримано 210 т живої ваги вибракуваних корів і бичків на відгодівлі. Сценарієм передбачається створення інфраструктури, що забезпечує виробництво 500 т твердих сирів $50 \%$ жирності, 400 т вершків або сметани $15 \%$ жирності, 90 т телятини та яловичини, біогазу з отриманням електро- й теплоенергії та органічних добрив, що залишаються після метанового бродіння на біогазовій станції. Для більш чіткого уявлення потенціал генерації біоенергії наводиться у перерахунку на газ-метан і його обсяги будуть становити 1,5 млн. м³ або $740 \mathrm{~m}^{3} /$ га [4].

Згідно існуючої градації грунт дослідної ділянки за фосфором має підвищену, за калієм - високу забезпеченість [5]. Це свідчить про те, що обсяги повернення цих елементів повинні складати відповідно 150 і 90 \% від виносу врожаєм. Отже для забезпечення оптимальної інтенсивності балансу фосфору в такій системі землеробства потрібно зовнішнє джерело його надходження. Ним може бути фосфоритне борошно або інші фосфорити природного походження [6].

Модель № 4 аналогічна до Моделі № 3 із залученням до структури посівних площ буряків цукрових $\mathrm{i}$ з їх переробкою та отриманням цукру. Середня по роках урожайність коренеплодів у нашому досліді склала 27 т/га, їх співвідношення до гички 1:0,4. Цим сценарієм передбачається включення до інфраструктури цукрового заводу. Головні очікувані переваги над попередньою моделлю - вища продуктивність буряків цукрових ніж кормових культур, супутне до основної продукції отримання соковитих кормів у вигляді гички та жому, можливість його систематичного включення до раціонів годівлі тварин у свіжому стані, значне підвищення засвоюваності концентрованих кормів шляхом додавання меляси.

Модель № 5. У разі впровадження Моделей № 3, або № 4 порівняно із рослинницькою спеціалізацією з біогумусом після переробки гною на біогаз у грунт буде повертатися більша частина винесених 3 урожаєм макро- та мікроелементів, що дасть змогу систематично поліпшувати його поживний режим. Приблизно така ж кількість компенсуючих відчуження мінеральних добрив у стаціонарному досліді дає змогу підвищити продуктивність сівозмін у середньому на $30 \%$. За вирощування зернових, зернобобових і круп'яних культур без мінеральних добрив і пестицидів у СТОВ «Колос 2000» можна буде в середньому отримувати 4,3 тис. т або 2,1 т/га продукції.

За Моделями № 1 і № 2 витрати на вирощування пшениці озимої, гороху, гречки, ячменю ярого та буряків цукрових встановлювали за даними 
Держкомстату [7] по середній за вісім років собівартості. У розроблених у 2015 p технологічних картах вирощування сільськогосподарських культур також наведені близькі показники [8]. При чому на мінеральні добрива та пестициди в технологічних процесах вирощування пшениці передбачається витратити $15 \%$, ячменю - $27 \%$, гороху - $28 \%$, гречки - $27 \%$ коштів.

Таблиця 1 - Валовий дохід, тис. у. о.

\begin{tabular}{|c|c|c|c|c|c|}
\hline \multirow{2}{*}{ Продукція } & \multicolumn{5}{|c|}{ Моделі } \\
\hline & № 1 & № 2 & № 3 & № 4 & № 5 \\
\hline \multicolumn{6}{|c|}{ Стандартна } \\
\hline Рослинництво & 920 & 1370 & $\begin{array}{lllll}- & & & & \end{array}$ & - & - \\
\hline Сир & $\begin{array}{l}- \\
\end{array}$ & - & 2441 & 2997 & 3855 \\
\hline Вершки & - & - & 885 & 1075 & 1397 \\
\hline М'ясо & - & - & 286 & 347 & 450 \\
\hline Цукор & - & - & - & 756 & 983 \\
\hline Електроенергія & - & - & 934 & 979 & 1275 \\
\hline Теплоенергія & - & - & 392 & 444 & 577 \\
\hline Добрива & - & - & 259 & 305 & 397 \\
\hline Разом & 920 & 1370 & 5195 & 6873 & 8934 \\
\hline Разом, у. о./га & 453 & 675 & 2559 & 3386 & 4401 \\
\hline \multicolumn{6}{|c|}{ Органічна } \\
\hline Рослинництво & 1740 & 4720 & - & - & - \\
\hline Сир & - & - & 6155 & 7478 & 9718 \\
\hline Вершки & - & - & 1206 & 1466 & 1905 \\
\hline М'ясо & - & - & 496 & 602 & 781 \\
\hline Цукор & - & - & - & 2466 & 3206 \\
\hline Електроенергія & - & - & 934 & 979 & 1275 \\
\hline Теплоенергія & - & - & 392 & 444 & 577 \\
\hline Добрива & - & - & 259 & 305 & 397 \\
\hline Разом & 1740 & 4720 & 9440 & 13740 & 17859 \\
\hline Разом, у. о./га & 857 & 2325 & 4650 & 6768 & 8797 \\
\hline
\end{tabular}

За сценарієм Моделі № 1 ціни реалізації на продукцію рослинництва приймали за середніми за вісім років даними Держкомстату з націнкою на органічні пшеницю, ячмінь і горох 100, на гречку - 60 \%. Так, якщо зерно пшениці та ячменю отримане за стандартною технологією продавалося по 170 у. о./т, гороху - 225 і гречки - 400 у. о./т, то реалізація цієї продукції як органічної дасть змогу отримати відповідно 340, 450 і 640 у. о./т.

Дохід від реалізації стандартної продукції встановлювали виходячи із середніх оптових цін у мережі Інтернет і використовуючи роздрібні ціни в мережі органічних магазинів «Натур Бутік» [9] без $100 \%$ торгової надбавки [10] (табл. 1). Стосовно запланованих обсягів виробництва по цих культурах (табл. 2) валовий дохід по підприємству складе 1,74 млн. у. о.

У цілому за рослинницької спеціалізації та за використання цін на стандартну продукцію без переробки сировини валовий дохід буде на рівні 1,7 млн. у. о. або 450 у. о./га, при переробці - 1,4 або 675 у. о./га, за створення 
різногалузевої структури з тваринництвом - 5,2 млн. у. о. або 2560 у. о./га, при ii доповненні галуззю буряківництва - 6,9 млн. у. о. або 3390 у. о./га, за підвищення продуктивності сівозміни на 30 \% - 8,9 млн. у. о або 4400 у. о./га. За реалізації продукції як органічної дохід зросте приблизно вдвічі.

\section{Таблиця 2 - Економічна ефективність різних моделей розвитку} підприсмства

\begin{tabular}{|l|c|c|c|c|c|}
\hline \multicolumn{1}{|c|}{ Показники } & \multicolumn{5}{c|}{ Моделі } \\
\cline { 2 - 6 } & № 1 & № 2 & № 3 & № 4 & № 5 \\
\hline Капітальні затрати, млн. у. о. & - & 0,2 & 6,1 & 7,2 & 9,2 \\
\hline Виробничі затрати, млн. у. о. & 0,6 & 0,7 & 0,9 & 1,3 & 1,7 \\
\hline Валовий дохід (стандартна), млн. у. о. & 0,9 & 1,4 & 5,2 & 6,9 & 8,9 \\
\hline Валовий дохід (органічна), млн. у. о. & 1,7 & 4,7 & 9,4 & 13,7 & 17,9 \\
\hline Чистий дохід (стандартна), млн. у. о. & 0,3 & 0,7 & 4,3 & 5,6 & 7,3 \\
\hline Чистий дохід (органічна), млн. у. о. & 1,1 & 4,0 & 8,6 & 12,0 & 16,2 \\
\hline Чистий дохід (стандартна), тис. у. о./га & 0,2 & 0,3 & 2,1 & 2,8 & 3,6 \\
\hline Чистий дохід (органічна), тис. у. о./га & 0,9 & 2,3 & 4,7 & 6,8 & 8,8 \\
\hline Строки окупності (стандартна), років & - & 1 & 2 & 2 & 2 \\
\hline Строки окупності (органічна), років & - & 1 & 1 & 1 & 1 \\
\hline
\end{tabular}

Висновки. Існуючий потенціал біопродуктивності району дає змогу організувати збалансоване виробництво значних обсягів органічного продовольства та біоенергії з короткими термінами окупності капітальних затрат. При цьому для досягнення максимального ефекту важливо враховувати пріоритетність, черговість створення та потужність складових майбутньої інфраструктури. Збалансована стосовно особливостей регіону інфраструктура передбачає створення специфічної для конкретних умов низки замкнених технологічних циклів, де відходи одних $є$ цінною сировиною для інших. Широке впровадження таких систем у практику дасть змогу істотно підвищити ефективність і конкурентоспроможність аграрного сектору економіки, зокрема за рахунок зниження собівартості продукції як мінімум на 30 \% до нинішніх показників, та отримання чистого прибутку на рівні 10 тис. у. о. 3 гектара.

\section{Література}

1. Бойко П. І., Коваленко Н. П. Науково обгрунтовані сівозміни і система рільництва у великотоварному господарстві. Пропозиція. 2005. № 6. С. 38-42.

2. Бойчик I. М. Економіка підприємства: навч. посіб. 2-те вид., допов. І перероб. Київ: Атіка, 2007. 528 с.

3. Розробка грунтозахисних ресурсо- та енергозберігаючих систем ведення сільськогосподарського виробництва 3 використанням комп'ютерного програмного комплексу: рекомендації. Київ: Нора-Друк, 2002. 122 с.

4. Нормативи грунтозахисних контурно-меліоративних систем землеробства. Київ, 1998. С. 158.

5. Методика суцільного грунтово-агрохімічного сільськогосподарських угідь України. КНД / за ред. О. О. Созінова, Б. С. Прістера. Київ, 1994. 162 с. 
6. Брагін Ю. М., Аверин Ю. О., Смірнов Т. І. Нові види сировини. Мінеральні ресурси Украӥни. 1995. № 1. С. 2-5.

7. Статистичний збірник «Сільське господарство України» за 2016 рік. Київ: Державна служба статистики України, 2016. С. 2-246.

8. Технологічні карти вирощування сільськогосподарських культур: монографія / Тіщенко Л. М., Корнієнко С. І., Дубровін В. А. та ін. / за ред. Л. М. Тіщенка. Харків: ХНТУСГ, 2015. 273 с.

9. Магазин органічної продукції. URL: https://natur-boutique.ua/ (дата звернення 27.07.2020).

10. Органічний цукор - продукт майбутнього, який виробляється в Україні. URL: http://www.ukrsugar.com/uk/post/organicnij-cukor-produkt-majbutnogo-akijviroblaut-v-ukraini (дата звернення 27.07.2020)

\section{References}

1. Boyko, P. I. \& Kovalenko, N. P. (2005). Naukovo obgruntovani sivozminy i systema rilnytstva u velykotovarnomu hospodarstvi [Scientifically based crop rotations and farming system in large-scale economy]. Propozytsiya. 6. 38-42 [in Ukrainian].

2. Boychyk, I. M. (2007). Ekonomika pidpryyemstva [Economics of the enterprise]. Kyyiv: Atika [in Ukrainian].

3. Rozrobka gruntozakhysnykh resurso- ta enerhozberihayuchykh system vedennya silskohospodarskoho vyrobnytstva $\mathrm{z}$ vykorystannyam kompyuternoho prohramnoho kompleksu [Development of soil-protective resource- and energy-saving systems of agricultural production with the use of computer software: recommendations]. (2002). Kyiv: Nora-Druk [in Ukrainian].

4. Normatyvy gruntozakhysnykh konturno-melioratyvnykh system zemlerobstva [Standards of soil protection contour-reclamation systems of agriculture]. (1998). Kyiv [in Ukrainian].

5. Sozinova, O. O. \& Pristera, B. S. (Eds) (1994). Methods of continuous soil agrochemical monitoring of agricultural lands of Ukraine KND. Kyyiv [in Ukrainian].

6. Brahin, Yu. M., Averyn, Yu. O. \& Smirnov, T. I. (1995). Novi vydy syrovyny. Mineralni resursy Ukrayiny [New types of raw materials]. Mineral resources of Ukraine, 1. 2-5 [in Ukrainian].

7. Statystychnyy zbirnyk «Silske hospodarstvo Ukrayiny» za 2016 rik. [Statistical collection "Agriculture of Ukraine" for 2016]. (2016). Kyiv: Derzhavna sluzhba statystyky Ukrayiny, 2-246 [in Ukrainian].

8. Tishchenko, L. M., Korniyenko, S. I....\& Dubrovin, V. A. (2015). Tekhnolohichni karty vyroshchuvannya silskohospodarskykh kultur [Technological maps of growing crops]. In: L. M. Tishchenka (Ed.). Kharkiv: KhNTUS [in Ukrainian].

9. Organics shop. (2020). Retrieved from https://natur-boutique.ua/

10. Organic sugar is a product of the future, which is produced in Ukraine. (2020). Retrieved from http://www.ukrsugar.com/uk/post/organicnij-cukor-produkt-majbutnogo-akij-viroblaut-vukraini

Abstract. In this publication, we will assess the potential of bioproductivity of typical chernozem in the Eastern Forest-Steppe of Ukraine in the system of organic farming, develop promising models of agricultural production with organic crop and livestock products with a high level of profitability. We will analyze five promising options for enterprise development, including the production of various types of organic products: organic grain; processing of organic grain into food; development of animal husbandry and bioenergy, cultivation and processing of sugar beet roots; increasing the productivity of crop rotations due to the high level of recycling of nutrients with organic fertilizers of animal origin.

Key words: organic farming, models, income, chernozem, productivity, efficiency.

СКудря С. І., Тараріко Ю. О., Кудря Н. А., Дегтярьова 3. О. 